\title{
Mortality and disability reported after immunoglobulins or plasmapheresis treatment of Guillain-Barré syndrome
}

\author{
Edinson Dante Meregildo-Rodriguez ${ }^{1}$, Victor Hugo Bardales-Zuta ${ }^{2}$ \\ ${ }^{1}$ Internal Medicine, Universidad César Vallejo, Escuela de Medicina, Trujillo, Perú; \\ ${ }^{2}$ Internal Medicine, Universidad Privada Antenor Orrego. Trujillo, Perú
}

Article received 28 October, 2021; accepted 10 November, 2021

\section{SUMMARY}

Objective: To compare the clinical results (28-day mortality and disability at discharge) in patients with Guillain-Barré Syndrome (GBS) treated with immunoglobulin or plasmapheresis at the Regional Lambayeque in Peru Hospital.

Patients and methods: Retrospective Cohort Study. Brighton criteria was used for diagnosing GBS, and modified Rankin scale (MRS) was employed for evaluating functional outcome. We used logistic regression for data analyses.

Results: A total of 142 cases of GBS diagnosed from 2011 to 2020 were included. GBS presented in a seasonal pattern; $60 \%$ of cases occurred in winter and spring. Motor variants (AMAN and AMSAN) accounted for $60 \%$ of cases, whereas only $8.5 \%$ of cases were typical GBS (AIDP). About $60 \%$ of patients were males, and $56 \%$ of cases corresponded to the age range of $20-59$ years. Patients aged $\geq 60$ years accounted for only $24 \%$ of total cases of GBS, but this group had a lethality of $58.3 \%$. Although 28 -day mortality was statistically similar in both treatment groups (plasmapheresis or immunoglobulin), we found a trend toward lower mortality in the plasmapheresis group (OR 0.78; 95\% CI 0.62- 0.97; $\mathrm{p}=0.062$ ). We found no differences in terms of disability at discharge in GBS patients treated with plasmapheresis or immunoglobulin.

Conclusion: Mortality and functional outcome were statistically similar between patients treated with immunoglobulin or plasmatic exchange. However, there was a trend toward lower mortality in patients treated with plasmapheresis.

Keywords: Guillain-Barré syndrome, mortality, disability, therapy.

\section{INTRODUCTION}

$G$ uillain-Barré syndrome (GBS) encompasses I several ascending sensory-motor polyneuropathies, often characterized by acute flaccid paralysis and abolition of tendon reflexes. There may be weakness of the facial, bulbar, and respiratory muscles. The sensitive and autonomic involvement is variable [1-3].

The diagnosis of GBS is often based on clinical evaluation and confirmation is made with electrophysiological studies and analysis of cerebro-

\section{Corresponding author}

Edinson Dante Meregildo-Rodriguez

E-mail: dante_meregildo@hotmail.com spinal fluid. However, some patients may have normal results in both tests, particularly during the first days of evolution $[4,5]$.

GBS is described as an immune-mediated disease, produced by an aberrant immune response, triggered by respiratory or gastrointestinal (viral or bacterial) infections, vaccines, or toxins [5, 6]. GBS is the most important etiology of acute flaccid paralysis worldwide. The annual incidence of GBS in the United States (USA) and Europe has been estimated to be $0.6-2.5$ per 100000 populationyears $[1,2,4]$. In Peru, about 300 to 600 GBS cases are recorded annually [6-9].

Plasmapheresis or immunoglobulin is recommended for patients with GBS who present within the initial 4 weeks of illness. Also, it is advisable to treat those cases that do not improve after 4 weeks 
of illness [10-14]. However, due to the significant heterogeneity of studies and the quality of available evidence, the universal validity of these conclusions remains questionable [15-24]. Furthermore, there are only a few clinical trials that have evaluated the effectiveness of plasmapheresis or immunoglobulin in the treatment of GBS types. Some small observational studies have suggested that plasmapheresis would be more effective than intravenous immunoglobulin in all GBS variants $[23,24]$.

The prognosis of patients with GBS is variable. Approximately $60-80 \%$ of patients are able to walk 6 months after the onset of the disease, regardless of whether or not they received treatment [21-23]. More than $90 \%$ of patients recover completely one year after the onset of the disease [19]. However, $20 \%$ or more of patients with GBS could be left with neurological sequelae, and mortality could reach up to $20 \%$, depending on various factors such as access and timing of specific therapy, monitoring units, critical support, and specific patient-related factors $[19,25,26]$.

The information on GBS available in Peru remains scarce [6-9, 27-30]. There are reports that have evaluated some clinical-epidemiological characteristics of these patients. However, there are no large studies that have evaluated clinical outcomes from primary sources, nor have they performed a comparative analysis of both treatment options. Thus, in this present study, we aimed to compare the clinical results (28-day mortality and disability degree at discharge) in patients with GBS treated with immunoglobulin or plasmapheresis in the Hospital Regional Lambayeque (HRL) of Peru.

\section{PATIENTS AND METHODS}

\section{Samples}

We included all cases (children and adults) of GBS treated with immunoglobulin or plasmapheresis between November 2011 and April 2020. Data were collected from the departments of emergency, critical care, pediatrics, and medicine of HRL, which is a third-level teaching center located in the northern coast of Peru. A non-probabilistic sampling was carried out for convenience. The reasons for exclusion were as follows: incomplete registration of information or cases of GBS that had not received treatment with either immunoglobulin or plasmapheresis.
Type of study

This is a retrospective cohort study.

\section{Variables}

Independent variable was treatment (immunoglobulin or plasmapheresis). Dependent variables were 28-day mortality and functional outcome (disability degree at discharge) according to the Modified Rankin Scale (MRS). Intervening variables were as follows: age, sex (gender), origin (department of origin), Guillain-Barré syndrome (diagnostic certainty was made using the Brighton criteria), and type of GBS (according to electromyographic criteria and clinical evaluation by a neurologist). We considered the following types: acute demyelinating inflammatory polyradiculopathy (AIDP), acute axonal motor neuropathy (AMAN), acute axonal motor-sensory neuropathy (AMSAN), Miller Fisher syndrome, and others. Other intervening variables were as follows: duration of illness (days elapsed between the onset of illness and admission to hospital), therapeutic delay (days elapsed between the onset of the disease and the start of treatment), complications (need for invasive mechanical ventilation, pneumothorax, pneumonia, septic shock, and pressure ulcers), hospital stay (days of hospitalization due to GBS or its complications), severity (Sequential Organ Failure Assessment [SOFA] score at admission), and comorbidity (Charlson Comorbidity Index at admission).

\section{Data collection and analysis}

The medical records of the patients were meticulously reviewed. The disability degree was established by a neurologist and/or rehabilitation physician. We elaborated a database, and data was analyzed using the statistical software SPSS ${ }^{\circledR}$ 26.0. Normality was verified, and quantitative data were presented in medians and interquartile ranges, and qualitative variables were expressed in frequencies. In the bivariate analysis, we used Pearson's $\mathrm{Xi}^{2}$ or Fisher's exact tests and the logistic regression model for multivariate analysis. A significance level of 0.05 and a confidence interval (CI) of $95 \%$ were considered. The variables for which the $p$-value was $\leq 0.05$ in the bivariate analysis were included in the final logistic regression model. We then calculated the odds ratios (OR) for independent variables associated with mortality and functional outcome. The associa- 
tion of the independent variables was expressed as OR with $95 \%$ CI. All tests were two-tailed, and a p-value $\leq 0.05$ was considered statistically significant.

\section{Ethical aspects}

We protected the confidentiality of patient information. Informed consent was not requested. This study was approved by the HRL Research Ethics Committee.

\section{RESULTS}

\section{Clinical-epidemiological characteristics}

In total, we included 142 GBS patients in this study, who presented during the period from November 2011 to April 2020 (Table 1). Most GBS cases occurred during the last 3 years of followup $(2018,2019$, and 2020) and during the winter and summer seasons, and, proportionally, more cases of the motor forms were observed during these months, although these differences were not statistically significant $(\mathrm{p}=0.595)$ (Figure 1$)$. No differences were found between the two groups (immunoglobulin and plasmapheresis), except in the therapeutic delay time, which was greater in the plasmapheresis group compared to the immunoglobulin group (median of 2 days versus 1 day, respectively) (Table 2).

\section{Mortality}

In the bivariate analysis, we found that the variables associated with 28-day mortality were Charlson score, MRS $\geq 4$, the need for invasive mechanical ventilation (IMV), septic shock, pneumonia, pneumothorax, therapeutic delay time, and SOFA score (Table 3 ). In the multivariate analysis, after adjusting for covariates, only the SOFA score was determined to be significantly associated with mortality (Table 4).

\section{Functional outcome}

In the bivariate analysis, we found that the variables associated with poor functional outcome (MRS $\geq 4$ ) were AMAN and AMSAN variants, IMV, septic shock, pneumonia, pressure ulcers, pneumothorax, and SOFA score (Table 5). In the multivariate analysis after adjusting for confounding covariates, only SOFA score was statistically significant associated with worse functional outcome (MRS $\geq 4$ ) (Table 6).
Table 1 - Clinical-epidemiological characteristics of GBS cases.

\begin{tabular}{|c|c|c|}
\hline Variable & $N=142$ & $\%$ \\
\hline $\begin{array}{l}\text { Age groups (years) Median [RIC] } \\
<10 \\
10-19 \\
20-59 \\
\geq 60\end{array}$ & $\begin{array}{c}40,5[22-58] \\
17 \\
12 \\
79 \\
34\end{array}$ & $\begin{array}{c}- \\
12 \\
8,5 \\
55,6 \\
23,9\end{array}$ \\
\hline $\begin{array}{l}\text { Sex } \\
\text { Female } \\
\text { Male }\end{array}$ & $\begin{array}{l}56 \\
86\end{array}$ & $\begin{array}{l}39,4 \\
60,6\end{array}$ \\
\hline $\begin{array}{l}\text { Season } \\
\text { Spring } \\
\text { Summer } \\
\text { Autumn } \\
\text { Winter }\end{array}$ & $\begin{array}{l}40 \\
24 \\
33 \\
45\end{array}$ & $\begin{array}{l}28,2 \\
16,9 \\
23,2 \\
31,7\end{array}$ \\
\hline $\begin{array}{l}\text { Charlson Score } \\
0-2 \\
\geq 3\end{array}$ & $\begin{array}{c}113 \\
29\end{array}$ & $\begin{array}{l}79,3 \\
20,6\end{array}$ \\
\hline $\begin{array}{l}\text { Modified Rankin Scale } \\
0-3 \\
\geq 4\end{array}$ & $\begin{array}{l}57 \\
85\end{array}$ & $\begin{array}{l}40,1 \\
59,9\end{array}$ \\
\hline $\begin{array}{l}\text { GBS type } \\
\text { AIDP } \\
\text { AMAN } \\
\text { AMSAN } \\
\text { MFS } \\
\text { No electromyography }\end{array}$ & $\begin{array}{c}12 \\
42 \\
43 \\
9 \\
36\end{array}$ & $\begin{array}{c}8,5 \\
29,6 \\
30,3 \\
6,3 \\
25,4\end{array}$ \\
\hline $\begin{array}{l}\text { Albumin-cytological dissociation } \\
\text { Not } \\
\text { Yes } \\
\text { No lumbar puncture }\end{array}$ & $\begin{array}{c}8 \\
37 \\
97\end{array}$ & $\begin{array}{r}5,6 \\
26,1 \\
68,3\end{array}$ \\
\hline $\begin{array}{l}\text { Brighton criteria (diagnostic } \\
\text { certainty) } \\
1 \\
2 \\
3\end{array}$ & $\begin{array}{l}27 \\
77 \\
38\end{array}$ & $\begin{array}{l}19,0 \\
54,2 \\
26,8\end{array}$ \\
\hline $\begin{array}{l}\text { Hospital stay* (days) Median [RIC] } \\
\leq 9 \text { days } \\
10-14 \\
15-29 \\
30-59 \\
\geq 60 \\
\text { SOFA* Score Median [RIC] }\end{array}$ & $\begin{array}{c}19[12-36] \\
18 \\
30 \\
47 \\
33 \\
14 \\
1[1-4]\end{array}$ & $\begin{array}{c}- \\
12,7 \\
21,1 \\
33,1 \\
23,2 \\
9,9 \\
-\end{array}$ \\
\hline $\begin{array}{l}\text { Clinical outcome at 28-day } \\
\text { Alive } \\
\text { Dead }\end{array}$ & $\begin{array}{c}130 \\
12\end{array}$ & $\begin{array}{c}91,5 \\
8,5\end{array}$ \\
\hline $\begin{array}{l}\text { Fatality rate by age group } \\
<10 \\
10-19 \\
20-59 \\
\geq 60\end{array}$ & $\begin{array}{l}0 \\
2 \\
3 \\
7\end{array}$ & $\begin{array}{r}0,0 \\
16,7 \\
25,0 \\
58,3\end{array}$ \\
\hline
\end{tabular}

${ }^{*}$ Median $\left[\right.$ RIC],${ }^{* *}$ Chi square, ${ }^{* * *}$ Fisher. 
Figure 1 - Frequency of cases of Guillain-Barré Syndrome (GBS) from 2011 to 2020, according to season and clinical form, Hospital Regional Lambayeque.

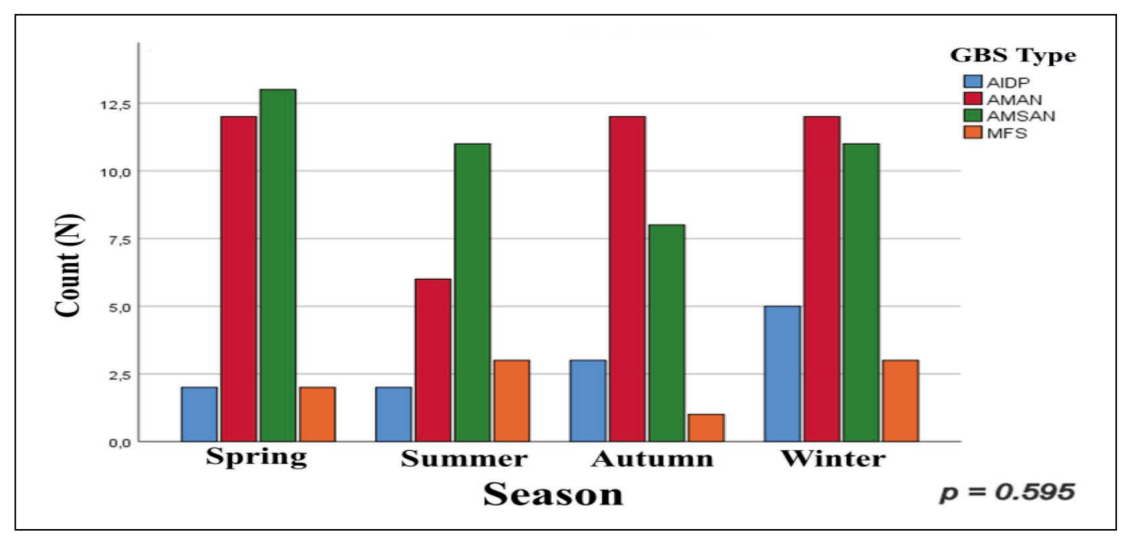

Table 2 - Clinical-epidemiological characteristics of GBS cases according to treatment received (IVIG or PF).

\begin{tabular}{|c|c|c|c|c|c|}
\hline \multirow{2}{*}{ Variable } & \multirow{2}{*}{$n$} & \multirow{2}{*}{$\%$} & \multicolumn{2}{|c|}{ Treatment } & \multirow{2}{*}{ p-value } \\
\hline & & & IVIG $(N=79)$ & $F P(N=63)$ & \\
\hline $\begin{array}{l}\text { Mortality } \\
\text { Not } \\
\text { Yes } \\
\text { Age }^{*}\end{array}$ & $\begin{array}{r}130 \\
12 \\
4 \\
\end{array}$ & $\begin{array}{r}91,5 \% \\
8,5 \% \\
2,0-58,0] \\
\end{array}$ & $\begin{aligned} & 75(94,9) \\
& 4(5,1) \\
& 38,0 {[14,0-57,0] } \\
&\end{aligned}$ & $\begin{array}{c}55(87,3) \\
8(12,7) \\
44[25-60] \\
\end{array}$ & $\begin{array}{c}0,200^{* * *} \\
0,085\end{array}$ \\
\hline $\begin{array}{l}\text { Sex } \\
\text { Female } \\
\text { Male }\end{array}$ & $\begin{array}{l}32 \\
68 \\
\end{array}$ & $\begin{array}{l}32,0 \\
68,0\end{array}$ & $\begin{array}{l}18(27,7) \\
47(72,3)\end{array}$ & $\begin{array}{l}14(40,0) \\
21(60,0)\end{array}$ & $0,128^{* *}$ \\
\hline $\begin{array}{l}\text { Charlson Score } \\
0-2 \\
\geq 3\end{array}$ & $\begin{array}{c}113 \\
29\end{array}$ & $\begin{array}{l}79,3 \\
20,6\end{array}$ & $\begin{array}{l}64(81,0) \\
15(19,0)\end{array}$ & $\begin{array}{l}49(77,8) \\
14(22,2)\end{array}$ & $0,635^{* *}$ \\
\hline $\begin{array}{l}\text { Modified Rankin Scale } \\
0-3 \\
\geq 4\end{array}$ & $\begin{array}{l}36 \\
64 \\
\end{array}$ & $\begin{array}{l}36,0 \\
64,0 \\
\end{array}$ & $\begin{array}{l}23(35,4) \\
42(64,6) \\
\end{array}$ & $\begin{array}{l}13(37,1) \\
22(62,9) \\
\end{array}$ & $0,861^{* *}$ \\
\hline Duration of illness (days)* & & $4[3-6]$ & $4[2-7]$ & $5[3-6]$ & 0,750 \\
\hline Therapeutic delay time (days)* & & $1[0-2]$ & $1[0-1]$ & $2[1-3]$ & 0,000 \\
\hline $\begin{array}{l}\text { GBS type } \\
\text { AIDP } \\
\text { AMAN } \\
\text { AMSAN } \\
\text { MFS } \\
\text { Not classified } \\
\end{array}$ & $\begin{array}{c}12 \\
42 \\
43 \\
9 \\
36\end{array}$ & $\begin{array}{c}8,5 \\
29,6 \\
30,3 \\
6,3 \\
25,4 \\
\end{array}$ & $\begin{array}{c}6(7,6) \\
23(29,1) \\
22(27,8) \\
8(10,1) \\
20(25,3) \\
\end{array}$ & $\begin{array}{c}6(9,5) \\
19(30,2) \\
21(33,3) \\
1(1,6) \\
16(25,4) \\
\end{array}$ & $\begin{array}{l}0,871^{* * *} \\
0,709^{* * *} \\
0,092^{* * *} \\
0,165^{* * *}\end{array}$ \\
\hline $\begin{array}{l}\text { Albumin-cytological dissociation } \\
\text { Not } \\
\text { Yes }\end{array}$ & $\begin{array}{c}8 \\
37\end{array}$ & $\begin{array}{c}5,6 \\
26,1\end{array}$ & $\begin{array}{c}4(5,1) \\
26(32,9)\end{array}$ & $\begin{array}{c}4(6,3) \\
11(17,5)\end{array}$ & $0,071^{* * *}$ \\
\hline Hospital stay (days)* & & 19 [12-36] & 18 [12-33] & 19 [12-37] & 0,954 \\
\hline Invasive Mechanical Ventilation & 41 & 28,9 & $24(30,4)$ & $17(27,0)$ & $0,657^{* *}$ \\
\hline Septic shock & 23 & 16,2 & $14(17,7)$ & $9(14,3)$ & $0,493^{* *}$ \\
\hline Pneumonia & 46 & 32,4 & $24(30,4)$ & $22(34,9)$ & $0,566^{* *}$ \\
\hline Pressure ulcers & 14 & 9,9 & $6(7,6)$ & $8(12,7)$ & $0,311^{* * *}$ \\
\hline Pneumothorax & 5 & 3,5 & $1(1,3)$ & $4(6,3)$ & $0,103^{* * *}$ \\
\hline Atelectasis & 18 & 12,7 & $13(16,5)$ & $5(7,9)$ & $0,130 * * *$ \\
\hline$S O F A^{*}$ & & 1 [1-4] & 1 [1-3] & 1 [1-4] & 0,350 \\
\hline
\end{tabular}

${ }^{*}$ Median $\left[\right.$ RIC],${ }^{* *}$ Chi square, ${ }^{* * *}$ Fisher. 
Table 3 - Bivariate analysis: factors associated with 28-day mortality in patients with GBS.

\begin{tabular}{|c|c|c|c|c|}
\hline \multirow{2}{*}{ Variable } & \multicolumn{4}{|c|}{ Outcome } \\
\hline & Alive $(N=132)$ & Dead $(N=12)$ & $O R^{*}\left(C I^{* *} 95 \%\right)$ & $P$ \\
\hline $\begin{array}{l}\text { Treatment } \\
\text { Immunoglobulin } \\
\text { Plasmapheresis }\end{array}$ & $\begin{array}{l}75(57,7) \\
55(42,3) \\
\end{array}$ & $\begin{array}{l}4(33,3) \\
8(66,7) \\
\end{array}$ & $0,62(0,52-1,19)$ & 0,075 \\
\hline$A g e^{*}$ & $38,0[14,0-57,0]$ & $44[25-60]$ & & 0,095 \\
\hline $\begin{array}{l}\text { Sex } \\
\text { Female } \\
\text { Male } \\
\end{array}$ & $\begin{array}{l}53(40,8) \\
77(59,2)\end{array}$ & $\begin{array}{l}3(25,0) \\
9(75,0)\end{array}$ & $2,22(1,67-4,02)$ & 0,318 \\
\hline $\begin{array}{l}\text { Charlson Score } \\
0-2 \\
\geq 3\end{array}$ & $\begin{array}{c}107(82,3) \\
23(17,7)\end{array}$ & $\begin{array}{l}6(50,0) \\
6(50,0)\end{array}$ & $2,50(1,76-4,96)$ & 0,018 \\
\hline $\begin{array}{l}\text { Modified Rankin Scale } \\
0-3 \\
\geq 4\end{array}$ & $\begin{array}{l}56(43,1) \\
74(56,9) \\
\end{array}$ & $\begin{array}{c}1(8,3) \\
11(91,7) \\
\end{array}$ & $3,21(2,61-6,36)$ & 0,001 \\
\hline Duration of illness (days)* & $4[3-6]$ & $6[3,25-6,75]$ & $0,96(0,79-4,03)$ & 0,727 \\
\hline Therapeutic delay time (days)* & $1[0-2]$ & $2[2-2,75]$ & $2,20(1,65-4,07)$ & 0,002 \\
\hline $\begin{array}{l}\text { GBS type } \\
\text { AIDP } \\
\text { AMAN } \\
\text { AMSAN } \\
\text { MFS } \\
\text { Not classified } \\
\end{array}$ & $\begin{array}{c}11(8,5) \\
39(30,0) \\
40(30,8) \\
7(5,4) \\
33(25,4) \\
\end{array}$ & $\begin{array}{c}1(8,3) \\
3(25,0) \\
3(25,0) \\
2(16,7) \\
3(25,0) \\
\end{array}$ & $\begin{array}{l}2,80(2,19-5,37) \\
1,89(1,84-4,44) \\
3,12(2,31-8,88) \\
1,90(1,89-4,37) \\
\end{array}$ & $\begin{array}{l}0,752 \\
0,187 \\
0,712 \\
0,245\end{array}$ \\
\hline Hospital stay (days)* & $18,5[12-35,25]$ & $25,5[18-55,5]$ & $1,24(0,69-5,02)$ & 0,302 \\
\hline Invasive Mechanical Ventilation & $32(24,6)$ & $9(75,0)$ & $2,68(1,99-8,74)$ & 0,000 \\
\hline Septic shock & $18(13,8)$ & $5(41,7)$ & $2,09(2,07-5,99)$ & 0,012 \\
\hline Pneumonia & $37(28,5)$ & $9(75,0)$ & $3,06(1,55-9,29)$ & 0,001 \\
\hline Pressure ulcers & $13(10,0)$ & $1(8,3)$ & $1,08(1,04-1,24)$ & 0,053 \\
\hline Pneumothorax & $3(2,3)$ & $2(16,7)$ & $3,66(1,97-8,40)$ & 0,010 \\
\hline Atelectasis & $15(11,5)$ & $3(25,0)$ & $1,95(1,08-10,7)$ & 0,180 \\
\hline SOFA* & $1[1-2]$ & $8[4,25-9,75]$ & $3,96(1,68-8,12)$ & 0,001 \\
\hline
\end{tabular}

*OR: Odds Ratio; ${ }^{* *} \mathrm{CI}$ : Confidence Interval.

\section{DISCUSSION}

Clinical-epidemiological characteristics

About $72 \%$ of GBS cases occurred during the last 3 years of follow-up. This is explained by the fact that in Peru, during recent years, GBS cases have presented in outbreaks, and the major outbreaks of GBS occurred during the years 2018 and 2019 [6-9]. During the first months of 2020, a significant number of cases began to be registered, which subsequently decreased owing to the arrival of COVID-19 to Peru. Regarding the impact that the COVID-19 pandemic has had on GBS in Peru, according to the Peruvian Ministry of Health, in 2020, were recorded 455 GBS cases (almost all oc- curred during the first 12 epidemiological weeks). This contrasts with the estimated 1100 GBS cases recorded in 2019 [31].

In this present study, we observed a seasonal pattern, that is, $60 \%$ of cases of GBS occurred in winter and spring (Table 1). The motor variants (AMAN and AMSAN) occurred more frequently during winter and spring compared with autumn and summer, although these differences were not statistically significant (Figure 1). The information available on the seasonal presentation of GBS worldwide is not consistent. In some countries, a few authors reported more cases of GBS in winter, while other studies found more cases of GBS in spring and summer [32-34]. In Chile, Cea G et al. 
Table 4 - Multivariate analysis: factors associated with 28-day mortality in patients with GBS.

\begin{tabular}{|c|c|c|c|c|c|c|}
\hline \multirow{2}{*}{ Variable } & \multicolumn{3}{|c|}{ Raw } & \multicolumn{2}{|c|}{ Adjusted } & \multirow{2}{*}{$p$} \\
\hline & OR & CI 95\% & $p$ & OR & CI $95 \%$ & \\
\hline $\begin{array}{l}\text { Treatment } \\
\text { Immunoglobulin } \\
\text { Plasmapheresis }\end{array}$ & $\begin{array}{c}1 \\
0,72\end{array}$ & $1,06-28,4$ & 0,01 & $\begin{array}{c}1 \\
0,78\end{array}$ & $0,62-0,9761$ & 0,062 \\
\hline $\begin{array}{l}\text { Charlson Score } \\
0-2 \\
\geq 3\end{array}$ & $\begin{array}{c}1 \\
4,07\end{array}$ & $0,67-42,08$ & 0,07 & $\begin{array}{c}1 \\
1,83\end{array}$ & $0,12-27,600$ & 0,666 \\
\hline $\begin{array}{l}\text { Modified Rankin Scale } \\
0-3 \\
4-6\end{array}$ & $\begin{array}{c}1 \\
1.227\end{array}$ & $1.731-5.895$ & 0.880 & $\begin{array}{c}1 \\
1.227\end{array}$ & $1.731-5.895$ & 0.880 \\
\hline $\begin{array}{l}\text { Invasive Mechanical Ventilation } \\
\text { Not } \\
\text { Yes }\end{array}$ & $\begin{array}{c}1 \\
1.075\end{array}$ & $0.902-3.160$ & 0.999 & $\begin{array}{c}1 \\
1.075\end{array}$ & $0.902-3.160$ & 0.999 \\
\hline $\begin{array}{l}\text { Shock } \\
\text { Not } \\
\text { Yes }\end{array}$ & $\begin{array}{c}1 \\
0.919\end{array}$ & $0.645-4.652$ & 0.932 & $\begin{array}{c}1 \\
0.919\end{array}$ & $0.645-4.652$ & 0.932 \\
\hline $\begin{array}{l}\text { Pneumonia } \\
\text { Not } \\
\text { Yes }\end{array}$ & $\begin{array}{c}1 \\
1.020\end{array}$ & $0.320-3.253$ & 0.999 & $\begin{array}{c}1 \\
1.020\end{array}$ & $0.320-3.253$ & 0.999 \\
\hline $\begin{array}{l}\text { Pneumothorax } \\
\text { Not } \\
\text { Yes }\end{array}$ & $\begin{array}{c}1 \\
0.180\end{array}$ & $1.122-4.884$ & 0.180 & $\begin{array}{c}1 \\
0.180\end{array}$ & $1.122-4.884$ & 0.180 \\
\hline $\begin{array}{l}\text { SOFA score } \\
<2 \\
\geq 2\end{array}$ & $\begin{array}{c}1 \\
3.333\end{array}$ & $1,63-7,59$ & 0,001 & 1 & $1,61-10,82$ & 0,003 \\
\hline $\begin{array}{l}\text { Therapeutic delay time (days)* } \\
\leq 1 \\
\geq 2\end{array}$ & $\begin{array}{c}1 \\
1,175\end{array}$ & $0,994-1,797$ & 0,180 & $\begin{array}{c}1 \\
3,792\end{array}$ & $0,540-26,627$ & 2,627 \\
\hline
\end{tabular}

${ }^{*}$ OR: Odds Ratio; ${ }^{* *} \mathrm{CI}$ : Confidence Interval.

found clear seasonal variations, with the majority of GBS cases occurring during winter and summer [23]. In Peru, Munayco et al., in a descriptive study of secondary databases reported that they did not find a seasonal pattern, although the occurrence of cases was higher in the first semester of the year [6]. Conversely, Loayza considered that the 2019 outbreak in Peru did have a seasonal pattern [7]. Ballón-Manrique et al. in one study carried out in our hospital reported a series of 16 cases of GBS, wherein $68.8 \%$ of them presented in winter and spring [9].

In this study, only $8.5 \%$ of cases corresponded to the AIDP form, and motor forms (AMAN and AMSAN) accounted for $60 \%$ of cases. In Peru, $70 \%$ of GBS cases presented during the 2019 outbreak corresponded to the motor axonal forms, which is associated with longer recovery time and more disability [7]. In USA, Canada, and Australia, up to $90 \%$ of GBS cases present as the AIDP variant, and only $5 \%$ correspond to motor axonal variants $[26,33]$. In Asia, $70 \%$ of cases are of the axonal type (AMAN), whereas $<25 \%$ of cases are of the AIDP variant or other types [35]. In Chile, in a series of 41 cases, 27 cases corresponded to the AIDP type and 9 cases to the motor variants [23]. BallónManrique found that $62.5 \%$ corresponded to motor forms (AMSAN 37.5\%; AMAN 25\%), 6.25\% to the MFS variant, and only $12.5 \%$ corresponded to the AIDP type [9]. These latter data are in full agreement with our results.

Only $19 \%$ of cases had the highest diagnostic certainty on the Brighton criteria, with the majority of cases $(54.2 \%)$ corresponding to level 2 of certainty. No previous studies reported in Latin America evaluated the degree of diagnostic cer- 
tainty. We used the Brighton criteria according to Peruvian guideline recommendations [36, 37].

As per our findings, most of the GBS patients were male $(>60 \%)$, and most cases occurred in the age range of 20-59 years, whereas the age range of $\geq 60$ years represented only $24 \%$ of the total GBS cases. The overall fatality rate was $8.5 \%$; however, in the group aged 20-59 years, it was found responsible for $25 \%$ of the deaths, and in the group $\geq 60$ years, it accounted for more than $58 \%$ of deaths. Our results are consistent with other reports in different latitudes, that is, GBS predominates in young adult males, while mortality is higher in older adults. Previous studies in our country are also in agreement with these findings, and this trend has been consistent in recent years [6-9, 27-30].
Of the total number of patients with GBS, only $20.6 \%$ had a Charlson score $\geq 4$; that is, most of GBS patients had little or no co-morbidity. Likewise, $50 \%$ of patients had a SOFA score of 1 ; that is, most patients were not severely ill $(50 \%$ of patients had a mild to moderate clinical picture). Interestingly, among the deceased patients, $50 \%$ had a Charlson score $\geq 3$, with 8 as the median SOFA [IQR 4.25-9.75], 75\% had pneumonia and required mechanical ventilation, and $42 \%$ had septic shock. Almost all studies of GBS have not examined these aspects (co-morbidity and severity).

Alshekhlee A et al. studied a cohort obtained from a national database in the United States. They identified 4954 patients with GBS hospitalized between 2000 and 2004. Mortality was $2.58 \%$, and it

Table 5 - Bivariate Analysis: factors associated with disability at discharge in patients with GBS.

\begin{tabular}{|c|c|c|c|c|}
\hline \multirow{2}{*}{ Variable } & \multicolumn{3}{|c|}{ Disability at discharge } & \multirow{2}{*}{$p$} \\
\hline & $M R S \leq 3(N=57)$ & $M R S \geq 4(N=85)$ & OR (CI 95\%) & \\
\hline $\begin{array}{l}\text { Treatment } \\
\text { Immunoglobulin } \\
\text { Plasmapheresis }\end{array}$ & $\begin{array}{l}33(57,9) \\
24(42,1)\end{array}$ & $\begin{array}{l}46(54,1) \\
39(45,9)\end{array}$ & $0,55(1,11-22,01)$ & 0,062 \\
\hline$A g e^{*}$ & $41,0[16,5-61,0]$ & $40[22,0-58,0]$ & $1,79(1,64-8,874)$ & 0,899 \\
\hline $\begin{array}{l}\text { Sex } \\
\text { Female } \\
\text { Male }\end{array}$ & $\begin{array}{l}29(50,9) \\
28(49,1)\end{array}$ & $\begin{array}{l}27(31,8) \\
58(68,2)\end{array}$ & $2,41(2,19-10,11)$ & 0,315 \\
\hline $\begin{array}{l}\text { Charlson Score } \\
0-2 \\
\geq 3\end{array}$ & $\begin{array}{c}49(86,0) \\
8(14,0)\end{array}$ & $\begin{array}{l}64(75,3) \\
21(24,7)\end{array}$ & $1,30(0,94-7,88)$ & 0,028 \\
\hline Duration of illness (days)* & 5 [3-7] & $4[3,0-6,0]$ & $2,19(0,95-9,62)$ & 0,612 \\
\hline Therapeutic delay time (days)* & $1[0-2]$ & $2[1-2,0]$ & $1,55(1,00-5,15)$ & 0,560 \\
\hline $\begin{array}{l}\text { GBS type } \\
\text { AIDP } \\
\text { AMAN } \\
\text { AMSAN } \\
\text { MFS } \\
\text { Not classified }\end{array}$ & $\begin{array}{c}17(29,8) \\
20(35,1) \\
4(7,0) \\
13(22,8)\end{array}$ & $\begin{array}{c}25(29,4) \\
23(27,1) \\
2(5,9) \\
23()\end{array}$ & $\begin{array}{l}2,67(1,80-8,33) \\
3,18(5,0110,45) \\
2,90(1,87-9,00) \\
1,39(1,09-4,02)\end{array}$ & $\begin{array}{l}0,022 \\
0,012 \\
0,052 \\
0,347\end{array}$ \\
\hline Hospital stay (days)* & $15,0[10,5-27,0]$ & $23[15,0-46,5]$ & $1,20(0,84-6,47)$ & 0,189 \\
\hline Invasive Mechanical Ventilation & $1(1,8)$ & $40(47,1)$ & $2,62(1,88-8,69)$ & 0,001 \\
\hline Septic shock & $0(0,0)$ & $23(27,1)$ & $2,90(1,89-12,1)$ & 0,000 \\
\hline Pneumonia & $1(1,8)$ & $45(52,9)$ & $1,97(1,90-9,87)$ & 0,001 \\
\hline Pression ulcers & $0(0,0)$ & $14(16,5)$ & $1,69(1,60-5,04)$ & 0,000 \\
\hline Pneumothorax & $0(0,0)$ & $5(5,9)$ & $1,86(1,23-7,36)$ & 0,001 \\
\hline Atelectasis & $0(0,0)$ & $18(21,2)$ & $2,11(1,02-8,00)$ & 0,239 \\
\hline SOFA score ${ }^{*}$ & $1[1-1]$ & $8[1-5]$ & $5,317(1,78-10,1)$ & 0,001 \\
\hline
\end{tabular}

*OR: Odds Ratio; ${ }^{* *} \mathrm{CI}$ : Confidence Interval. 
did not change significantly during the entire period. About $11 \%$ of patients presented pulmonary complications, and $9.1 \%$ underwent endotracheal intubation. Predictors of mortality were endotracheal intubation, older age, Charlson Comorbidity Index, cardiac complications, and sepsis. The authors concluded that mortality in GBS is low and that the predictors of mortality are similar to the predictors of disability [38].

Wong AH et al. retrospectively reviewed 261 GBS cases in seven Asian hospitals that occurred between 2001 and 2012. The overall mortality was determined to be $6 \%$. The main cause of death was respiratory infections, followed by acute myocardial infarction. Among the deceased, 50\% were over 77 years of age, $50 \%$ required IMV, and almost all had significant co-morbidities. Older patients with need for IMV had a higher risk of mortality [39].
In this present study, only $12.7 \%$ of patients had an "adequate" hospital stay ( $\leq 9$ days) according to the Peruvian hospital performance indicators; $66 \%$ of the patients had a hospital stay $>14$ days, which is a median of 19 days [IQR 12-36]. Gevorgyan A et al. investigated trends in hospital stay and mortality according to the treatment method, that is, immunoglobulin vs. plasmapheresis, and compared them between teaching and non-teaching hospitals. The follow-up period was from January 2000 to December 2011. The authors concluded that from 2000 to 2011, adult GBS cases presented the following trends: the use of PF decreased; the use of IVIG increased; hospital stay decreased; and mortality decreased. These trends did not differ between teaching and non-teaching hospitals [40].

The main variables of interest presented similarly

Table 6 - Multivariate analysis: factors associated with disability at discharge in patients with GBS.

\begin{tabular}{|c|c|c|c|c|c|c|}
\hline \multirow{2}{*}{ Variable } & \multicolumn{3}{|c|}{ Raw } & \multicolumn{2}{|c|}{ Adjusted } & \multirow{2}{*}{$p$} \\
\hline & OR & CI 95\% & $p$ & OR & CI 95\% & \\
\hline $\begin{array}{l}\text { Treatment } \\
\text { Immunoglobulin } \\
\text { Plasmapheresis }\end{array}$ & $\begin{array}{c}1 \\
0,72\end{array}$ & $0,68-1,987$ & 0,01 & $\begin{array}{c}1 \\
0,69\end{array}$ & $0,51-7,69$ & 0,054 \\
\hline $\begin{array}{l}\text { Charlson Score } \\
0-2 \\
\geq 3\end{array}$ & $\begin{array}{c}1 \\
3,79\end{array}$ & $1,90-11,09$ & 0,07 & $\begin{array}{c}1 \\
3,13\end{array}$ & $0,99-7,460$ & 0,666 \\
\hline $\begin{array}{l}\text { Modified Rankin Scale } \\
0-3 \\
4-6\end{array}$ & $\begin{array}{c}1 \\
1.248\end{array}$ & $1,022-5.97$ & 0.180 & $\begin{array}{c}1 \\
2,49\end{array}$ & $1.301-2.801$ & 0,087 \\
\hline $\begin{array}{l}\text { Invasive Mechanical Ventilation } \\
\text { Not } \\
\text { Yes }\end{array}$ & $\begin{array}{c}1 \\
2,471\end{array}$ & $0,127-3,96$ & 0,470 & $\begin{array}{c}1 \\
2,07\end{array}$ & $1,712-9,201$ & 0,589 \\
\hline $\begin{array}{l}\text { Septic shock } \\
\text { Not } \\
\text { Yes }\end{array}$ & $\begin{array}{c}1 \\
1,299\end{array}$ & $1,045-8,342$ & 0,601 & $\begin{array}{c}1 \\
1,345\end{array}$ & $0,780-4,047$ & 0,932 \\
\hline $\begin{array}{l}\text { Pneumonia } \\
\text { Not } \\
\text { Yes }\end{array}$ & $\begin{array}{c}1 \\
2,707\end{array}$ & $1,832-3,873$ & 0,199 & $\begin{array}{c}1 \\
1,027\end{array}$ & $0,320-4,793$ & 0,799 \\
\hline $\begin{array}{l}\text { Pneumothorax } \\
\text { Not } \\
\text { Yes }\end{array}$ & $\begin{array}{c}1 \\
2,180\end{array}$ & $1,049-10,08$ & 0,080 & $\begin{array}{c}1 \\
4,007\end{array}$ & $1.122-14.784$ & 0.180 \\
\hline $\begin{array}{l}\text { SOFA score } \\
<2 \\
\geq 2\end{array}$ & $\begin{array}{c}1 \\
3,287\end{array}$ & $1,63-7,59$ & 0,001 & 1 & $1,68-11,87$ & 0,001 \\
\hline $\begin{array}{l}\text { Therapeutic delay time (days)* } \\
\leq 1 \\
\geq 2\end{array}$ & $\begin{array}{c}1 \\
1,942\end{array}$ & $0,794-1,797$ & 0,180 & $\begin{array}{c}1 \\
3,498\end{array}$ & $0,540-26,627$ & 2,627 \\
\hline
\end{tabular}

${ }^{*}$ OR: Odds Ratio; ${ }^{* *} \mathrm{CI}$ : Confidence Interval. 
in both treatment groups, with the exception of the variable "therapeutic delay time". The median time of therapeutic delay was longer in those who received plasmapheresis $(p<0.000)$ (Table 2). However, this difference in therapeutic initiation time did not influence mortality or functional outcome. The therapeutic delay in our hospital is explained by the fact that administering plasmapheresis compared with immunoglobulin is more laborious from a logistical point of view. In most studies that have evaluated treatments for GBS, the initiation time of immunoglobulin or plasmapheresis has not been reported. In one trial that compared both treatments, the protocol only stipulated that treatment should be started within 8 hours after randomization [41].

\section{Mortality}

Regarding 28-day mortality, no differences were noted between immunoglobulin and plasmapheresis. However, we found a trend toward lower mortality in the plasmapheresis group (OR 0.78; $95 \%$ CI 0.62-0.97; $\mathrm{p}=0.062$ ) compared with the immunoglobulin group (Table 4). Cea G et al., in a retrospective analysis, included 41 patients with GBS and reported a non-significant trend for less disability but not mortality in those patients treated with plasmapheresis compared with immunoglobulin [23]. Other studies, most of them with a retrospective design and carried out in different latitudes, have evaluated different aspects of mortality related to GBS. They included different populations and different settings; consequently, these studies are more difficult to compare with our results [42-45].

\section{Functional outcome}

Regarding functional outcome, no differences were observed between immunoglobulin and plasmapheresis. The only variable statistically and significantly associated with a worse functional outcome (MRS $\geq 4$ ) was SOFA score (Table 6). A trial published in 1997 compared the efficacy of immunoglobulin, plasmapheresis, and immunoglobulin combined with plasmapheresis for GBS. The inclusion criteria were as follows: severe illness (need for help to walk) and onset of neuropathic symptoms within the previous 14 days. The authors evaluated 379 patients. They found no differences among the treatment arms with respect to the main (disability degree at 4 weeks) and secondary outcomes (recovery time to walk without assistance, time to discontinue IMV, and trend for recovery from disability at 48 weeks). They concluded that for the treatment of severe GBS in the first 2 weeks of illness, plasmapheresis and immunoglobulin had equivalent efficacy [41]. Siddiqui SH et al. conducted a retrospective study between 2011 and 2016 in Pakistan to determine the short-term outcomes of GBS and compare the outcomes of ventilated and non-ventilated patients. They included 216 patients, who were then divided into two groups based on the need for IMV. Short-term outcomes were assessed using the MRS at discharge, 2 weeks, and 3 months; these were then compared between the IMV and non-IMV group. Similarly, as in our study, the outcome according to MRS was dichotomized as "good" (MRS $=0-3$ ) or poor (MRS = 4-6). They found that $24.5 \%$ of patients required IMV. The patients who required IMV had severe weakness on admission, a longer hospital stay, and a higher frequency of in-hospital complications. They reported a mortality of $7.9 \%$. Good outcomes at discharge and at 3 months were significantly more frequent in non-ventilated patients $(50.3 \%$ and 93.2, respectively) compared to ventilated patients (11.3\% and 33.3\% respectively). In the IMV group, older age, areflexia, and longer hospital stay were independent predictors of poor outcomes [46]. Hughes RA et al. performed a systematic review, aiming to evaluate the efficacy of immunoglobulin (functional recovery and morbidity). They identified 12 studies, 7 of which had a variable risk of bias and evaluated immunoglobulin compared to plasmapheresis in 623 severe cases. In five studies that included 536 cases, disability was similar with both treatment groups. Adverse events were comparable across treatment groups, but more patients completed immunoglobulin than plasmapheresis [18].

In Chile, Cea G et al. found differences in disability according to the type of GBS. At discharge, $59.2 \%$ of GBS patients with the AIDP type presented minor disability, $22.2 \%$ required assistance to walk, and $3.7 \%$ were totally dependent. Patients with the AMAN variant were noted to have greater disability: $57 \%$ of patients required help to walk and $28.5 \%$ were bedridden. On the other hand, $68.4 \%$ of those who received plasmapheresis had a greater recovery compared with $44.4 \%$ of those who received immunoglobulin, although 
this difference was not statistically significant [23]. In Peru, no studies have evaluated disability in GBS patients.

This present study has some limitations. First, this is a retrospective study carried out in a single hospital. Second, we have failed to identify the triggering agent (infection, vaccines, toxins, etc.) in almost all patients because in our hospital this is not performed systematically. Despite these limitations, this study is relevant as it is the first study of primary sources that includes the largest Peruvian population.

In conclusion, in this study, although 28-day mortality was statistically similar in both treatment groups (immunoglobulin and plasmapheresis), we found a trend toward lower mortality in the PF group (OR 0.78; 95\% CI 0.62-0.97; $p=0.062$ ). We found no differences in disability at discharge in GBS patients treated with plasmapheresis or immunoglobulin.

\section{Conflict of interest}

None to declare.

\section{Grants and funding}

None to declare.

\section{REFERENCES}

[1] Willison HJ, Jacobs BC, van Doorn PA. GuillainBarré syndrome. Lancet. 2016; 388 (10045, 717,27. doi: 10.1016/S0140-6736(16)00339-1.

[2] Malek E, Salameh J. Guillain-Barré Syndrome. Semin Neurol. 2019; 39 (5), 589-95. doi: 10.1055/s-0039-1693005.

[3] Leonhard SE, Mandarakas MR, Gondim FAA, et al. Diagnosis and management of Guillain-Barré syndrome in ten steps. Nat Rev Neurol. 2019; 15 (11), 671-83. doi: 10.1038/s41582-019-0250-9.

[4] Van den Berg B, Walgaard C, Drenthen J, et al. Guillain- Barré syndrome: pathogenesis, diagnosis, treatment and prognosis. Nat Rev Neurol. 2014; 10 (8), 46982. doi: $10.1038 /$ nrneurol.2014.121

[5] Asbury AK, Cornblath DR. Assessment of current diagnostic criteria for Guillain- Barré syndrome. Ann Neurol. 1990; 27, S21-S24. doi: 10.1002/ana.410270707.

[6] Munayco CV, Soto MG, Reyes MF, et al. Epidemiología del síndrome de Guillain-Barré en el Perú. Rev Peru Med Exp Salud Publica. 2019; 36 (1), 10-6. doi: 10.17843/rpmesp.2019.361.3729.

[7] Loayza-Alarico MJ, De la Cruz-Vargas JA, Alatrista MDS. Guillain-Barré syndrome, epidemic outbreak in Peru in June 2019. Salud Publica Mex. 2019; 61 (5), 556-7. doi: $10.21149 / 10731$.
[8] Díaz-Soto S, Chavez K, Chaca A, et al. Outbreak of Guillain-Barre syndrome in Perú. eNeurologicalSci. 2019; 14, 89-90. doi: 10.1016/j.ensci.2019.02.001.

[9] Ballón-Manrique B, Campos-Ramos N. Características clínicas y paraclínicas del Síndrome de GuillainBarré en el Hospital Regional Lambayeque. Rev Neuropsiquiatr. 2017; 80 (1), 22-6.

[10] Leonhard SE, Mandarakas MR, Gondim FAA, et al. Diagnosis and management of Guillain-Barré syndrome in ten steps. Nat Rev Neurol. 2019; 15 (11), 671-83. doi: 10.1038/s41582-019-0250-9.

[11] Alva-Diaz C, Mori N, Pacheco-Barrios K, et al. Clinical practice guideline for the diagnosis and treatment of Guillain-Barre syndrome. Neurol Argentina. 2020; 3648. doi: https:/ / doi.org/10.1016/j.neuarg.2019.09.006

[12] Meena AK, Khadilkar SV, Murthy JM. Treatment guidelines for Guillain-Barré Syndrome. Ann Indian Acad Neurol. 2011; 14 (Suppl 1), S73-81. doi: 10.4103/09722327.83087.

[13] Korinthenberg R, Trollmann R, Felderhoff-Müser $\mathrm{U}$, et al. Diagnosis and treatment of Guillain-Barré Syndrome in childhood and adolescence: An evidence- and consensus-based guideline. Eur J Paediatr Neurol. 2020; 25, 5-16. doi: 10.1016/j.ejpn.2020.01.003.

[14] Sudulagunta SR, Sodalagunta MB, Sepehrar M, et al. Guillain-Barré syndrome: clinical profile and management. Ger Med Sci. 2015; 13: Doc16. doi: 10.3205/000220.

[15] Raphaël JC, Chevret S, Hughes RA, Annane D. Plasma exchange for Guillain-Barré syndrome. Cochrane Database Syst Rev. 2012. doi: 10.1002/14651858.CD001798

[16] Ortiz-Salas P, Velez-Van-Meerbeke A, Galvis-Gomez CA, et al. Human immunoglobulin versus plasmapheresis in Guillain-Barre Syndrome and Myasthenia Gravis: a meta-analysis. Clin Neuromuscul Dis. 2016; 18 (1), 1-11. doi: 10.1097/CND.0000000000000119.

[17] Hughes RA, Swan AV, Raphaël JC, et al. Immunotherapy for Guillain-Barré syndrome: a systematic review. Brain. 2007; 130 (Pt 9), 2245-57. doi: 10.1093/brain/ awm004.

[18] Hughes RA, Swan AV, van Doorn PA. Intravenous immunoglobulin for Guillain-Barré syndrome. Cochrane Database of Systematic Reviews 2014, Issue 9. Art. No.: CD002063. doi: 10.1002/14651858.CD002063.pub6

[19] Bersano A, Carpo M, Allaria S, et al. Long term disability and social status change after Guillain-Barré syndrome. J Neurol. 2006; 253 (2), 214-8. doi: 10.1007/ s00415-005-0958-x.

[20] Oczko-Walker M, Manousakis G, Wang, S, et al. Plasma exchange after initial intravenous immunoglobulin treatment in Guillain-Barré syndrome: critical reassessment of effectiveness and cost-efficiency. $J$ Clin Neuromuscul Dis. 2010; 12 (2), 55-61. doi: 10.1097/ CND.0b013e3181f3dbbf

[21] El-Bayoumi MA, El-Refaey AM, Abdelkader AM, et al. Comparison of intravenous immunoglobulin and plasma exchange in treatment of mechanically ventilated 
children with Guillain- Barré syndrome: a randomized study. Crit Care. 2011; 15 (4), R164. doi: 10.1186/cc10305 [22] Michon B, Moghrabi A, Winikoff R, et al. Complications of apheresis in children. Transfusion. 2007; 47 (10), 1837-42. doi: 10.1111/j.1537-2995.2007.01405.x

[23] Cea G, Jara P, Quevedo F. Características epidemiológicas del síndrome de Guillain-Barré en población chilena: estudio hospitalario en un período de 7 años. Rev Med Chil. 2015; 143 (2), 183-9. doi: 10.4067/S003498872015000200005.

[24] Sinanović O, Zukić S, Burina A, et al. Plasmapheresis in neurological disorders: six years experience from University Clinical Center Tuzla. F1000Res. 2017; 6, 1234. doi: 10.12688/f1000research.11841.1.

[25] van den Berg B, Walgaard C, Drenthen J, et al. Guillain-Barré syndrome: pathogenesis, diagnosis, treatment and prognosis. Nat Rev Neurol. 2014; 10 (8), 469-82. doi: 10.1038/nrneurol.2014.121.

[26] van Doorn PA. Diagnosis, treatment and prognosis of Guillain-Barré syndrome (GBS). Presse Med. 2013; 42 (6 Pt 2), e193-201. doi: 10.1016/j.lpm.2013.02.328.

[27] Rodríguez-Morales AJ, Failoc-Rojas VE, DíazVélez C. Gastrointestinal, respiratory and/or arboviral infections? What is the cause of the Guillain-Barré syndrome epidemics in Perú? Current status - 2019. Travel Med Infect Dis. 2019; 30, 114-6. doi: 10.1016/j. tmaid.2019.06.015.

[28] Apaza N. Características clínicas y electrofisiológicas del Síndrome de Guillain-Barré en el Instituto Nacional de Ciencia Neurológicas, 2008-2012 [thesis of Specialization]. Lima: Universidad Nacional Mayor de San Marcos; 2014. Retrieved from: https://pesquisa. bvsalud.org/portal/resource/pt/lil-713940?lang=es [29] Crovetto L. Variantes clínicas-neurofisiológicas del Síndrome de Guillain-Barré. Rev. Peru. Neurol. 1990; 2 (2-3), 64-72.

[30] Jaimez A, Ormea A. Perfil clínico del Síndrome de Guillain-Barré: experiencia de 29 casos. Bol Soc Peru Med Interna. 1995; 8 (2), 20-5.

[31] Sistema de vigilancia epidemiológica CDC-MINSA. Situación del síndrome del Guillain-Barré Perú, 2020 a la SE 44. Retrieved from: https: / / www.dge.gob.pe/portalnuevo/vigilancia-epidemiologica/vigilancia-prevencion-y-control-del-sindrome-de-guillain-barre /

[32] Paolino E, Govoni V, Tola MR, et al. Incidence of the Guillain-Barre syndrome in Ferrara, northern Italy, 1981-1987. Neuroepidemiology. 1991; 10 (3), 105-11. doi: $10.1159 / 000110254$.

[33] Govoni V, Granieri E, Tola MR, et al. The frequency of clinical variants of Guillain-Barré syndrome in Ferrara, Italy. J Neurology. 1999; 246 (11), 1010-4.

[34] Rocha MS, Brucki SM, Carvalho AA, et al. Epidemiologic features of Guillain-Barré syndrome in Sao Paulo, Brazil. Arq. Neuro-Psiquiatr. 2004; 62 (1), 33-7. doi: 10.1590/S0004282X2004000100006

[35] McGrogan A, Madle GC, Seaman HE, et al. The epidemiology of Guillain-Barré syndrome worldwide. A systematic literature review. Neuroepidemiology. 2009; 32 (2), 150-63. doi: 10.1159/000184748.

[36] Instituto Nacional de Ciencias Neurológicas. Guía de práctica clínica para el diagnóstico y tratamiento del paciente con Síndrome de Guillain-Barré. INCN - MINSA; 2018. Retrieved from: https://www.gob.pe/institucion/minsa / normas-legales / 279121-201-2018-dgincn-guia-guillain-barre

[37] Instituto de Evaluación de Tecnologías en Salud e Investigación - IETSI. Guía de Práctica Clínica para el Diagnóstico y Tratamiento de Personas Con Síndrome de Guillain-Barré. Seguro Social de Salud - ESSALUD; 2019. Retrieved from: http://www.essalud.gob.pe/ ietsi/pdfs/tecnologias_sanitarias/GPC_SGB_Version_ corta2019.pdf

[38] Alshekhlee A, Hussain Z, Sultan B, et al. Guillain-Barré syndrome: incidence and mortality rates in US hospitals. Neurology. 2008; 70 (18), 1608-13. doi: 10.1212/01.wnl.0000310983.38724.d4.

[39] Wong AH, Umapathi T, Shahrizaila N, et al. The value of comparing mortality of Guillain-Barré syndrome across different regions. J Neurol Sci. 2014; 344 (1-2), 60-2. doi: 10.1016/j.jns.2014.06.021.

[40] Gevorgyan A, Sanossian N, Beydoun SR. GuillainBarré Syndrome Trend of Hospital Length of Stay, Complication Rate and Mortality Depending from Method of the Treatment: IVIg vs. PLEX (P5.137). Neurology. 2017; 88 (16 Supplement): P5.137.

[41] Plasma Exchange/Sandoglobulin Guillain-Barré Syndrome Trial Group. Randomised trial of plasma exchange, intravenous immunoglobulin, and combined treatments in Guillain-Barré syndrome. Lancet. 1997; 349 (9047), 225-30. doi: https:/ / doi.org/10.1016/S01406736(96)09095-2

[42] Van den Berg B, Bunschoten C, van Doorn PA, et al. Mortality in Guillain- Barré syndrome. Neurology. 2013; 80 (18), 1650-1654. doi: 10.1212/WNL.0b013e3182904fcc [43] Domínguez-Moreno R, Tolosa-Tort P, PatiñoTamez A, et al. Mortalidad asociada al diagnóstico de síndrome de Guillain-Barré en adultos ingresados en instituciones del sistema sanitario mexicano. Rev Neurol. 2014; 58 (1), 4-10.

[44] Korinthenberg R, Schessl J, Kirschner J. Clinical presentation and course of childhood Guillain- Barré syndrome: a prospective multicentre study. Neuropediatrics. 2007; 38 (1), 10-7. doi: 10.1055/s-2007-981686

[45] Dhar R, Stitt L, Hahn AF. The morbidity and outcome of patients with Guillain- Barré syndrome admitted to the intensive care unit. J Neurol Sci. 2008; 264 (12), 121-8. doi: 10.1016/j.jns.2007.08.005

[46] Siddiqui SH, Siddiqui TH, Babar MU, et al. Outcomes of patients with Guillain-Barré Syndrome - Experience from a tertiary care hospital of a developing Asian country and review of regional literature. J Clin Neurosci. 2019; 62, 195-8. doi: 10.1016/j.jocn.2018.11.031 